\title{
A betegség és a szociodemográfiai háttér hatása a cerebralis bénulásban szenvedő gyermekek életminőségére
}

\author{
Fejes Melinda dr. ${ }^{1}$ - Varga Beatrix dr. ${ }^{2}$ - Hollódy Katalin dr. ${ }^{3}$ \\ ${ }^{1}$ Borsod-Abaúj-Zemplén Megyei Központi Kórház és Egyetemi Oktató Kórház, \\ Újszülött Intenzív Osztály, Miskolc \\ ${ }^{2}$ Miskolci Egyetem, Gazdaságtudományi Kar, Gazdaságelméleti és Módszertani Intézet, Miskolc \\ ${ }^{3}$ Pécsi Tudományegyetem, Általános Orvostudományi Kar, Gyermekgyógyászati Klinika, Pécs
}

Bevezetés: A kutatócsoport 99 fö, cerebralis paresisben (CP) szenvedő gyermek (8-18 éves) önállóan közölt életminőségét értékelte, és az eredményeket összehasonlította egy 237 fős kontrollcsoport adataival, amelyek hasonló életkorú, egészséges általános populációhoz tartozó gyermekektől származtak.

Célkitüzés: A kutatás célja annak megismerése volt, hogy a CP-ben szenvedő gyermekek hogyan vélekednek egészségi állapotukról és társadalmi helyzetükről.

Módszer: Életminőség-kérdőív alkalmazása. Betegségspecifikus és társadalmi-demográfiai mutatók mérése, kiértékelése.

Eredmények: Az CP-ben szenvedő gyermekek és szüleik az egészséggel kapcsolatos életminőséget rosszabbnak ítélték meg, mint társaik. Eredményeink azt mutatják, hogy a női nem, a rosszabb motoros funkció és a komorbiditások (epilepszia, incontinentia és intellektuális károsodás) negatív hatású. A szülői vélemény alkalmas volt proxyjelentésként a korreláció mért erôssége miatt. Figyelemre méltó, hogy az agyi bénulás típusai közül az egyoldali spasticus CP-ben szenvedő gyermekek életminőség-értéke a legalacsonyabb. A válaszadók valószínúleg a test két oldala között lévő funkcionális különbséget érezték. A szellemi fogyatékosság a betegpopuláció több mint felénél fordult elő. Testvéreik között a mentális betegség 5,7-szer gyakoribb. A CP-s gyerekek családi környezete sokkal hátrányosabb volt, mint az egészséges gyermekeké. A kutatás eredményei alapján megállapítható, hogy a szülő alacsonyabb iskolai végzettsége és munkaerőpiaci inaktivitása, valamint az egyszülős család a CP-s gyerekeknél szignifikánsan magasabb arányban fordult elő, és ezek a tényezők negatív hatást gyakoroltak az életminőségre.

Következtetés: A fogyatékkal élő gyermekek életminőségét a betegség és a szociodemográfiai környezet egyaránt befolyásolja.

Orv Hetil. 2021; 162(7): 269-279.

Kulcsszavak: cerebralis paresis, gyermekek, serdülők életminősége, szülői vélemény, GMFCS-pontszám, cerebralis paresis típusa

\section{The impact of disease and sociodemographic background on children suffering from cerebral palsy}

Introduction: Self-reported health-related quality of life (HRQoL) of 99 children (8-18 years) with cerebral palsy (CP) was assessed and compared with 237, age-matched healthy control children from the general population. Objective: The aim was to find out the opinions of children with CP about their health status and social condition. Method: Assessment of quality of life questionnaire was carried out. Measurements of disease-specific and sociodemographic variables were done.

Results: Children with CP and their parents rated HRQoL poorer than their counterparts. Our results show that female sex, worse gross motor function and comorbidities (epilepsy, incontinence and intellectual impairment) had negative impact. The parental opinion was suitable as proxy report because of the measured strength of the correlation. Among the types of CP, interestingly, children with unilateral spastic CP had the poorest HRQoL. They were likely to feel a functional difference between the two sides of the body. Intellectual disability occurred in more than half of our patient population. Among their siblings, mental illness is 5.7 times more common. The family environ- 
ment was much more disadvantageous than in the case of healthy children. As our study shows, lower education, inactive status in the labour market and single-parent family occurred at a much higher rate and worsened the quality of life.

Conclusion: Quality of life of children with disability was influenced by both the sociodemographic background and the disease.

Keywords: cerebral palsy, quality of life of children, adolescents, parental opinion, GMFCS score, type of cerebral palsy

Fejes M, Varga B, Hollódy K. [The impact of disease and sociodemographic background on children suffering from cerebral palsy]. Orv Hetil. 2021; 162(7): 269-279.

(Beérkezett: 2020. július 13.; elfogadva: 2020. szeptember 17.)

\begin{abstract}
Rövidítések
ANOVA $=($ analysis of variance $)$ varianciaanalízis; ÁP $=$ általános populáció; $\mathrm{CD}=$ (intellectual disability) kognitív deficit; $\mathrm{CI}=$ (confidence interval) konfidenciaintervallum; $\mathrm{CP}=$ cerebralis paresis; ES = (effect size $)$ hatásmérték; GMFCS $=($ Gross Motor Function Classification System) a nagymotoros funkciók osztályozási rendszere; HRQoL = (health-related quality of life) az egészséggel kapcsolatos életminőség; IQ = (intelligence quotient) intelligenciahányados; $\mathrm{RR}=$ (relative risk $)$ kockázati arány; SCPE $=$ (Surveillance of Cerebral Palsy in Europe) az agyi bénulás felügyeletének európai hálózata; $\mathrm{SD}=$ standard deviáció; $\mathrm{T}$ = átlag-T-érték
\end{abstract}

Az agyi bénulás (cerebralis paresis, CP) olyan jelek és tünetek összessége, amelyekben a mozgásfogyatékosság dominál. Általános prevalenciája 2-4\%o, Magyarországon 2,1\%. A CP fó kockázati tényezői a koraszülöttség és az alacsony születési súly, leggyakoribb jele a spasticitas [1-4]. Gyakran komorbiditások - például epilepszia, értelmi fogyatékosság vagy incontinentia - kísérik. További ritkább rendellenességek a CP-betegekben a figyelemhiány, valamint a beszéd- és tanulási nehézségek. Minden egyes komorbiditás csökkentheti a CP-ben szenvedő gyermekek életminőségét [5-8]. Az elmúlt 60 évben az újszülöttek, különösen a koraszülöttek gyógykezelése jelentősen javult, mivel új gyógyszerek és korszerü technikák váltak elérhetővé. Ezeknek a nagyon beteg újszülötteknek a túlélési esélye jelentősen javult, de néhány gyermek súlyos vagy kevésbé súlyos motoros és/ vagy mentális sérülésben szenved.

Az egészséggel kapcsolatos életminőség (HRQoL) az egészség különböző dimenzióinak a beteg szempontjából történő értékelésére vonatkozik. Az utóbbi években sok tudományos vizsgálatot végeztek a CP HRQoL-re gyakorolt hatásáról [9-19]. Ezeknek a tanulmányoknak az eredményei azonban nem egységesek, néha ellentmondásosak, és általában csak a CP-vel rendelkező gyermekek szüleinek véleményén alapulnak [20-24].

A vizsgálat célja egyrészt a CP-ben szenvedő gyermekek életminőségének tanulmányozása, másrészt annak a hasonló életkorú általános népesség (ÁP ) életminőségé- vel való összehasonlítása volt. Elemzésre kerültek azok a betegséggel összefüggő tulajdonságok és szociodemográfiai tényezók, amelyek hatással lehetnek a CP-ben szenvedő gyermekek életminőségére. A vizsgálat nullhipotézise az volt, hogy a CP-vel rendelkező gyermekek életminőségét a betegség és a társadalmi helyzet egyaránt befolyásolja, valamint az, hogy önismereti képességük nem tér el szignifikánsan a hasonló ÁP-étől.

\section{Módszer}

KIDSCREEN-52 gyermek- és szülői kérdőívek adatainak kiértékelése. Az alkalmazott szociodemográfiai kérdőív egészséges és krónikus betegségben szenvedő gyermekek és serdülők számára is alkalmazható $[25,26]$.

\section{Beteg- és általános populáció}

A kutatás során 99, CP-ben szenvedő gyermeket nevelő család, valamint az ÁP-ból 200 család bevonására került sor. Az ÁP-ből a jobb statisztikai elemzés és későbbi, más irányú kutatás miatt több családot kértek fel. Ikrek nem voltak sem a beteg-, sem az ÁP-csoportban.

A résztvevők a következő helyszíneken, kilenc megyéből kerültek ki. A felmérésre a Pécsi Tudományegyetem Gyermekorvosi Osztályán, a Borsod-Abaúj-Zemplén Megyei Központi Kórház gyermekgyógyászati osztályain, valamint fogyatékkal élő gyermekeket segítő, speciális és/vagy általános iskolákban és intézményekben került sor. Az ÁP-t képviselő résztvevők Baranya megyéből és Borsod-Abaúj-Zemplén megyéből származtak. Az adatgyüjtés 2012 novemberétől 2016 februárjáig zajlott. A gyermekek normál vagy emelt szintű, speciális oktatásban részesültek, kognitív deficitük (CD) nem volt.

A kutatás során az anya végzettségéről, foglalkozásáról, a szülők családi állapotáról, a testvérek számáról és betegségeiről történt szociodemográfiai adatgyưjtés. A szülők végzettségével kapcsolatban három képzettségi szint került meghatározásra: alapfokú (legfeljebb 8 osztály), középfokú, valamint magas képzettségú szülők. A gazdasági aktivitás szerinti 2 csoport az aktív és az inak- 
tív (munkanélküli, háztartásbeli, nyugdíjas, hallgató) státusz volt. A családi kapcsolatok felosztása, a kétszülős család (házasság vagy együttélés) és az egyszülős család (elvált, özvegy, egyedülálló) volt. A testvérek krónikus betegségét a szülői jelzések alapján osztották az alábbi csoportokba: mozgásszervi, érzékszervi, értelmi és egyéb. A rendelkezésre álló adatok szerint genetikai, illetve szindromatológiai kivizsgálás néhány esetben történt. Ezenkívül a szerzők vizsgálták a CP-betegek megoszlását városi és vidéki lakhely szerinti csoportosításban is.

A szerzők törekedtek arra, hogy lehetőleg minden szülővel személyes kapcsolatot alakítsanak ki. Rendeléseken, iskolákban, bentlakásos intézményekben került sor a találkozásokra, illetve azokban az esetekben, akiknél ez nem volt lehetséges, levélben történt a kapcsolatfelvétel. A felmérés során a legtöbb gyermek képes volt a kérdőíveket önállóan kitölteni. Ahol a mozgáskárosodás akadályozta őket ebben, a szerzők, illetve az ápolószemélyzet fizikai segítséget nyújtott. A tanulási nehézségekkel küzdő (szellemi fogyatékos, dyslexiás) gyermekek is részt vehettek a kutatásban, de alapvető fontosságú volt, hogy a gyermek megértse a kérdéseket, és válaszolni tudjon rájuk. Ebben az esetben a szülők véleménye a reális megítéléshez elengedhetetlen volt. A krónikus betegséggel kapcsolatban rendelkezésre álltak adatok, mint például a CP típusa, a mozgáskorlátozottság szintje. A CP típusainak csoportosítása az SCPE által javasolt séma figyelembevételével történt: spasticus $\mathrm{CP}$, mely lehet egy- vagy kétoldali, ataxiás $\mathrm{CP}$, dyskineticus $\mathrm{CP}$, dystoniás, choreoathetoticus CP és nem besorolható CP [27] (1. táblázat).

A motoros fogyatékossággal élő gyermekek nagymotoros funkciójának meghatározása a nagymotoros funkciók osztályozási rendszerének (GMFCS) öt szintjével történt: I. szint: akadálytalan járás, csak a fejlettebb mozgások akadályozottak; II. szint: járás segédeszköz nélkül, nehézségek a szabadban és a tömegközlekedésben; III. szint: járás segédeszközzel, nehézségek a szabadban és a tömegközlekedésben; IV. szint: korlátozott mozgás, kültéren és/vagy a tömegközlekedésben kerekes székes szállításra, illetve elektromos eszközre van szükség; V. szint: az önellátás súlyosan sérült, még segédeszközökkel is, teljesen másokra utalt a beteg, a mozgás súlyosan akadályozott [28] (1. táblázat). Nemcsak a gyermekek motoros állapotát, hanem minden egyéb komorbiditást (intellektuális deficit, epilepszia, incontinentia stb.) is figyelembe vettek a kutatási tevékenység során. Az intelligencia mértéke a hivatalos vizsgálati adatokból került kigyưjtésre. A mérési módszert nem mindenhol jelezték az adatrögzítók (például bentlakásos intézetben), csak a mért értéket írták az adatbázisba. Ha a gyermek nemcsak tisztán motoros fogyatékossággal, hanem más, kapcsolódó rendellenességgel is rendelkezett (például aktív epilepsziával vagy értelmi fogyatékossággal: IQ 50-70), akkor a közepes CP (CP plusz egy másik fogyatékosság) vagy a súlyos CP (CP plusz két vagy több más fogyatékosság) csoportjába került.
1. táblázat A táblázat bemutatja betegeinknél a cerebralis paresis típusait az SCPE beosztása szerint, a gyakori társbetegségeket és a mozgássérülés súlyosságát a GMFCS 5 fokozatú rendszerében (betegszám/százalék)

\begin{tabular}{|c|c|c|}
\hline Mutatók & $\mathrm{n}$ & $\%$ \\
\hline \multicolumn{3}{|l|}{ CP-típusok } \\
\hline Spasticus egyoldali & 26 & 26,3 \\
\hline Spasticus kétoldali & 51 & 51,5 \\
\hline Dystoniás & 5 & 5,0 \\
\hline Choreoathetoticus & 1 & 1,0 \\
\hline Ataxiás & 7 & 7,1 \\
\hline Nem besorolható & 7 & 7,1 \\
\hline \multicolumn{3}{|l|}{ Társbetegségek } \\
\hline Kognitív deficit & 55 & 55,6 \\
\hline Aktív epilepszia & 16 & 16,2 \\
\hline Incontinentia & 15 & 15,2 \\
\hline Súlyos fogyatékosság* & 39 & 39,4 \\
\hline \multicolumn{3}{|l|}{ GMFCS-szintek } \\
\hline $\begin{array}{l}\text { I. szint: akadálytalan járás, csak a fejlettebb } \\
\text { mozgások akadályozottak }\end{array}$ & 21 & 21,2 \\
\hline $\begin{array}{l}\text { II. szint: járás segédeszköz nélkül, nehézségek } \\
\text { a szabadban és a tömegközlekedésben }\end{array}$ & 26 & 26,3 \\
\hline $\begin{array}{l}\text { III. szint: járás segédeszközzel, nehézségek a } \\
\text { szabadban és a tömegközlekedésben }\end{array}$ & 15 & 15,2 \\
\hline $\begin{array}{l}\text { IV. szint: korlátozott mozgás, kültéren és/vagy } \\
\text { a tömegközlekedésben kerekes székes szállításra, } \\
\text { illetve elektromos eszközre van szükség }\end{array}$ & 12 & 12,1 \\
\hline $\begin{array}{l}\text { V. szint: az önellátás súlyosan sérült, még } \\
\text { segédeszközökkel is, teljesen másokra utalt a beteg, } \\
\text { a mozgás súlyosan akadályozott }\end{array}$ & 20 & 20,2 \\
\hline Ismeretlen * * & 5 & 5,0 \\
\hline
\end{tabular}

$\mathrm{CP}=$ cerebralis paresis; GMFCS = a nagymotoros funkciók osztályozási rendszere; $S C P E=$ az agyi bénulás felügyeletének európai hálózata

*Súlyos fogyatékosság $=\geq 2$ társbetegség

** Ismeretlen = személyes vizsgálatra nem volt lehetőség, az adatbázisból nem derült ki egyértelmúen a mozgássérülés szintje

\section{Etika}

Etikai engedélyt a Pécsi Tudományegyetem Klinikai Központjának Regionális Tudományos és Kutatásetikai Bizottsága és a Borsod-Abaúj-Zemplén Megyei Kórház és Egyetemi Oktató Kórház Regionális, Intézményi Tudományos Kutatásetikai Bizottsága állított ki. Az életminőség-kérdőívet a gyermekek csak aláírt szülői beleegyezés mellett tölthették ki.

\section{Statisztikai analízis}

Az összegyưjtött adatokat a KIDSCREEN-52 kérdőívnek mind a 10 dimenzióját figyelembe véve értékeltük ki. A statisztikai elemzést az SSPS-19 statisztikai szoftver (IBM Corporation, Armonk, NY, Amerikai Egyesült 
Államok) alkalmazásával végeztük. Azokat a kérdőíveket, amelyeknél a válaszok több mint 10\%-a hiányzott, kihagytuk az elemzésből.

A KIDSCREEN-52 pontszámait a nemzetközi T-értékek szerint értelmeztük $[25,26]$. A teljes alappopuláció százalékos értékeit T-értékekké alakítottuk át, amelynél a nemzetközi populáció normálértékei: átlag: 50, SD: 10. Ezek alapján a magasabb T-érték magasabb HRQoL-t jelentett. A magyar értékek nem mutattak szignifikáns eltéréseket az európai értékekhez képest, kivéve a társadalmi elfogadottság/zaklatás területét, amely alacsonyabb értékú volt. A szülői értékelés nem különbözött az európai értékektől. Ebből azt a következtetést vontuk le, hogy a kutatás során rögzített ÁP-t jellemző minta alkalmazása szerencsésebb, mint a régi magyar értékek használata.

A CP-ben szenvedő és krónikus betegség nélküli gyermekek HRQoL-vizsgálata a leíró statisztikai mutatók közül a számtani átlag, a medián és a szórás mutatószámok alkalmazásával történt. A KIDSCREEN-52 valamennyi dimenziója kiértékelésre került. A kutatásnak részét képezte a CP-ben szenvedő gyerekek és az ÁP-t képviselő gyermekek válaszainak összehasonlítása, a gyermekek és a szülők válaszainak vizsgálata, valamint a különböző demográfiai-szociodemográfiai ismérvek, továbbá a betegség súlyossága szerint csoportosított eredmények értékelése. Tehát az egyes számításoknál a függő változók a következő csoportképző ismérvek voltak: nem, életkori csoportok, a testvérek száma, a szülő gazdasági aktivitása, a szülő iskolai végzettsége és a betegség súlyossága.

A statisztikai tesztek közül az ANOVA, a Mann-Whitney-féle U-teszt, a párosított t-próba, a khi-négyzet-próba és a korrelációszámítás került alkalmazásra.

A hatásmérték (ES) megállapítása a Cohen-féle d alkalmazásával történt, amely a két csoportátlag közötti különbséget viszonyítja az adatok szórásához. Az ES (d) nagyon kicsi $(0,01)$, kicsi $(0,2)$, közepes $(0,5)$, nagy $(0,8)$, nagyon nagy $(1,2)$ és óriási $(2,0)$ volt.

A kockázati arány ( $\mathrm{RR})$ a betegszámra való tekintettel $\pm 30 \%$-os különbséggel szignifikáns volt.

\section{Eredmények}

A KIDSCREEN-52 kérdőívet 99, CP-s gyermeket nevelő család, valamint 237 ÁP-s szülő és 236 ÁP-s gyermek töltötte ki. A CP-s gyermekek átlagéletkora 12 év 3 hónap volt, és 46\%-uk (46/99) volt 13 évesnél fiatalabb. Az ÁP-s gyermekek átlagéletkora 12 év 11 hónap volt, és 113 gyermek $(47,7 \%)$ nem töltötte még be a 13. évet. A CP-s gyerekek 57,6\%-a volt lány (57) és 42,4\%-a fiú (42). Az ÁP-t 116 fiú $(48,9 \%)$ és 127 lány $(51,1 \%)$ képviselte.

A szülői kérdőíveket fơként anyák töltötték ki (69/69,7\% CP; 207/87,3\% ÁP) 2. táblázat). A CP-családok a testvérekről nem töltöttek ki KIDSCREEN-52 kérdőívet, a testvérek számát, betegségét a szociodemográfiai kérdőíven jelezték.

A beteg gyermekek közel felének $(51 / 51,5 \%)$ spasticus kétoldali CP-je, negyedüknek $(26 / 26,3 \%)$ spasticus egyoldali CP-je volt. A gyermekek 55,6\%-ánál (55) közepes vagy enyhe szellemi fogyatékosság (IQ = 50-70), 16,2\%-ánál (16 beteg) aktív epilepszia, 15,2\%-ánál (15 beteg) pedig incontinentia társult az alapbetegséghez a kérdőív kitöltésekor. A tesztfelvétel idején az epilepsziás betegek a gyógyszeres kezelés mellett egyensúlyban voltak, gyakori rohamok nélkül. Több mint 2 társbetegség a CP-ben szenvedő gyermekek 39,4\%-ánál (39 beteg) fordult elő. A CP-ben szenvedő gyermekek 47,5\%-a (47 fó) segédeszköz nélkül tudott járni (GMFCS 1-2. szint) (1. táblázat).

Az elemzés az ÁP adatainak a KIDSCREEN értékeihez történő validálásával kezdődött. A szülők értékei nem különböztek szignifikánsan a KIDSCREEN-értékektől. Az eredmények alapján megállapítható, hogy a magyar ÁP-s gyermekek szociális elfogadottság/bántalmazás értékei pozitívabbak, mint az európai átlag. A bántalmazás kevésbé gyakori volt mind az ÁP-ben, mind a CP-populációban, mint a KIDSCREEN európai adataiban (EU: 71,35\%; ÁP: 95\%; CP: 90,8\% az elérhető pontszámból; $\mathrm{p}<0,05$, ES: 1,1).

A 3. táblázat a CP-s és az ÁP-s csoport gyermekeinek és szüleinek KIDSCREEN-átlagértékeit és azok szórásait mutatja. A CP-s gyerekek és szüleik összes kérdésre adott válaszainak átlaga nem tért el szignifikánsan (a párosított t-próba értéke $0,939, \mathrm{p}=0,35)$. Viszont mind a CP-ben szenvedő gyermekek, mind szüleik értékelése különbözött az ÁP-ből származó gyermekek és szüleik értékelésétől. A tíz KIDSCREEN-dimenzió összes kérdésére adott HRQoL-válaszok átlaga mind a szülők, mind a gyermekek esetében szignifikánsan alacsonyabb volt, mint az ÁP-t képviselő szülők és gyermekek átlaga

2. táblázat |A cerebralis paresisben szenvedő betegeink és az általános népesség jellemzó mutatói

\begin{tabular}{|c|c|c|}
\hline Mutatók & $\mathrm{CP}(\mathrm{n} / \%)$ & ÁP $(n / \%)$ \\
\hline Összes & $99 / 100$ & $237 / 100$ \\
\hline 8-12 év & $46 / 46,5$ & $113 / 47,7$ \\
\hline 13-18 év & $53 / 53,5$ & $124 / 52,3$ \\
\hline Kor (átlag \pm SD) & $\begin{array}{c}12 \text { év } \\
\text { (3 hó } \pm 7,5 \text { hó) }\end{array}$ & $\begin{array}{c}12 \text { év } \\
\text { (11 hó } \pm 7 \text { hó) }\end{array}$ \\
\hline Nem - Férfi & $42 / 42,4$ & $116 / 48,9$ \\
\hline - Nó & $57 / 57,6$ & $127 / 51,1$ \\
\hline \multicolumn{3}{|c|}{ A szülői tesztet kitöltötte } \\
\hline Anya & $69 / 69,7$ & $207 / 87,3$ \\
\hline Apa & $17 / 17,2$ & $22 / 9,3$ \\
\hline Más hozzátartozó & $9 / 9,1$ & $6 / 2,5$ \\
\hline Ismeretlen & $4 / 4,0$ & $2 / 0,9$ \\
\hline
\end{tabular}

ÁP = általános népesség; $\mathrm{CP}=$ cerebralis paresis; $\mathrm{SD}$ = standard deviá ció 
(szülők esetében 4,07 vs. $3,8, p=0,000$; gyermekek esetében 3,95 vs. $3,10, \mathrm{p}=0,000$ ).

A tíz KIDSCREEN-dimenziót külön-külön megvizsgálva a „fizikai jóllét”, a „hangulat/érzelmek”, a „pénzügyi helyzet”, a „társadalmi támogatás/barátok” és a „társadalmi elfogadottság és/vagy bántalmazás (bullying)" kategóriákat a CP-s gyermekek és szüleik szignifikánsan rosszabbnak ítélték meg, mint az ÁP gyermekei és szüleik (3. táblázat).

A gyermekek és szüleik értékelése között mind a CP-s családok, mind pedig az ÁP-s családok esetében pozitív közepesen erős vagy szoros kapcsolat mutatható ki vala- mennyi KIDSCREEN-dimenzió esetében. Figyelemre méltó, hogy valamennyi dimenzió esetében a CP-s családoknál a szülők és a gyermekek válaszai között szorosabb a korreláció, mint az ÁP-től kapott válaszoknál (3. és 4. táblázat).

Az életkort tekintve nem volt szignifikáns különbség a CP-s gyermekek és a serdülők életminősége között. A szignifikancia közelében csak az anyagi helyzet pontszáma volt $(\mathrm{p}<0,05 \mathrm{l}, \mathrm{ES}:-0,45)$ (4. táblázat).

A CP-s gyerekek esetében szignifikáns különbség mutatkozott a két nem válaszaiban. A lányok a saját teljes HRQoL-értékükeket rosszabbnak ítélték meg, mint a

3. táblázat |Átlag-T-értékek és azok szórásai (SD) a vizsgált csoportokban, kiegészítve Cohen-féle hatásmérték (ES)-számításokkal a különböző csoportok között. Az ANOVA leíró statisztika által számított átlag- és szórásértékek az általános populáció esetén az európai értékekhez, míg cerebralis paresis esetén az általános populációhoz kalkulált T-értékekben és szórásban vannak megadva (EU- és/vagy ÁP-átlag = 50, ÁP-szórás = 10 T-érték)

\begin{tabular}{|c|c|c|c|c|c|c|c|c|c|c|c|c|}
\hline \multirow[t]{3}{*}{ Dimenziók } & \multicolumn{6}{|c|}{ Gyermek } & \multicolumn{6}{|c|}{ Szülő } \\
\hline & \multicolumn{3}{|c|}{ ÁP } & \multicolumn{3}{|c|}{$\mathrm{CP}$} & \multicolumn{3}{|c|}{ ÁP } & \multicolumn{3}{|c|}{$\mathrm{CP}$} \\
\hline & $\mathrm{T}$ & $\pm \mathrm{SD}$ & ES-1 & $\mathrm{T}$ & $\pm \mathrm{SD}$ & ES-2 & $\mathrm{T}$ & $\pm \mathrm{SD}$ & ES-3 & $\mathrm{T}$ & $\pm \mathrm{SD}$ & ES-4 \\
\hline Összes & 51,8 & 8,6 & 0,17 & 50,65 & 10 & $0,08 * *$ & 54,10 & 8,60 & 0,06 & 51,27 & 10,4 & 0,03 ** \\
\hline Fizikai jóllét & 52,9 & 14,4 & 0,29 & 35,7 & 27,6 & $1,32 * *$ & 52,30 & 12,20 & 0,03 & 40,77 & 16,2 & $0,78^{* *}$ \\
\hline Pszichológiai jóllét & 53,6 & 13,8 & 0,36 & 52,51 & 16 & 0,08 & 59,00 & 11,20 & 0,12 & 52,7 & 14,2 & 0,06 \\
\hline Hangulatok és érzelmek & 55,3 & 10,6 & 0,53 & 53,38 & 13,2 & $0,15^{*}$ & 53,20 & 8,60 & 0,04 & 51,48 & 11,8 & 0,27 ** \\
\hline Önértékelés & 46,2 & 4,2 & $-0,38$ & 44,18 & 4,8 & 0,16 & 52,60 & 11,20 & 0,03 & 54,08 & 14,2 & $-0,52$ \\
\hline Autonómia & 52,2 & 17 & 0,22 & 51,54 & 17,8 & 0,05 & 50,60 & 15,20 & 0,01 & 50,2 & 17,8 & 0,12 \\
\hline Család & 53,4 & 12,6 & 0,34 & 54,75 & 12,6 & $-0,10$ & 53,60 & 12,40 & 0,05 & 55,21 & 11,6 & $-0,13$ \\
\hline Pénzügyi források & 52,9 & 21,6 & 0,28 & 42,75 & 27,2 & $0,78^{* *}$ & 54,00 & 20,40 & 0,05 & 46,77 & 26,6 & 0,32 ** \\
\hline Barátok & 53,8 & 16,8 & 0,8 & 48 & 19,8 & $0,44^{* *}$ & 5,90 & 15,00 & 0,05 & 48,86 & 20 & 0,29 ** \\
\hline Iskolai környezet & 55 & 15,8 & 0,5 & 58,9 & 13,6 & $-0,8$ & 54,0 & 13,0 & 0,06 & 55,15 & 14,4 & $-0,01$ \\
\hline Társadalmi elfogadás & 61 & 9,6 & $1,1^{*}$ & 51,7 & 14,6 & $0,6^{* 1}$ & 53,0 & 9,0 & 0,5 & 51,34 & 12 & $0,67^{*}$ \\
\hline
\end{tabular}

${ }^{*} \mathrm{p}<0,05 ;{ }^{* *} \mathrm{p}<0,001$

ANOVA = varianciaanalízis; ÁP = általános népesség; ES- 1 = Cohen-hatásmérték a KIDSCREEN európai adatai és az ÁP között, ES-2 = Cohen hatásmérték az ÁP- és a CP-gyermekek között; ES-3 = Cohen-hatásmérték a KIDSCREEN és az ÁP-szülők között; ES-4 = Cohen-hatásmérték az ÁP- és a CP-szüloók között; EU = Európai Unió; Összes = a tíz KIDSCREEN-dimenzió pontszámainak együttes értékelése; SD = standard deviáció; $\mathrm{T}$ = átlag-T-érték

4. táblázat |A cerebralis paresises populáció életminőségének gyermek-szülő, életkor és nem szerinti elemzése. Az ANOVA leíró statisztika által számított átlag- és szórásértékek az általános populációhoz kalkulált T-értékekben és szórásban vannak megadva (ÁP-átlag = 50, ÁP-szórás = 10 T-érték)

\begin{tabular}{|c|c|c|c|c|c|c|c|c|c|c|c|c|}
\hline \multirow[t]{3}{*}{ Dimenziók } & \multicolumn{2}{|c|}{ Gyermek-szülő } & \multicolumn{5}{|c|}{ Életkor } & \multicolumn{5}{|c|}{ Nem } \\
\hline & \multirow[b]{2}{*}{$\mathrm{r}$} & \multirow[b]{2}{*}{ ES-5 } & \multicolumn{2}{|c|}{ 8-12 év } & \multicolumn{2}{|c|}{ 13-18 év } & \multirow[b]{2}{*}{ ES-6 } & \multicolumn{2}{|c|}{ Férfi } & \multicolumn{2}{|c|}{ Nő } & \multirow[b]{2}{*}{ ES-7 } \\
\hline & & & T-érték & $\pm \mathrm{SD}$ & T-érték & $\pm \mathrm{SD}$ & & T-érték & $\pm \mathrm{SD}$ & T-érték & $\pm \mathrm{SD}$ & \\
\hline Összes & 0,831 ** & $-0,01$ & 50,75 & 10 & 50,45 & 10 & 0,02 & 51,94 & 9,2 & 48,63 & 10,6 & $0,54^{*}$ \\
\hline Fizikai jóllét & 0,278 & $-0,02$ & 44,14 & 18,8 & 42,03 & 15,8 & 0,28 & 43,48 & 16,6 & 42,42 & 19,6 & 0,17 \\
\hline Pszichológiai jóllét & $0,747^{*}$ & $-0,001$ & 53,28 & 12,8 & 51,68 & 17,8 & 0,23 & 54,7 & 13,2 & 50,26 & 17,4 & 0,52 * \\
\hline Hangulatok és érzelmek & $0,714^{*}$ & 0,02 & 54,48 & 13,4 & 52,3 & 13 & 0,29 & 55,04 & 11,8 & 50,65 & 13,8 & 0,61 * \\
\hline Önértékelés & $0,552^{*}$ & $-0,15$ & 42,93 & 4,8 & 44,81 & 4,8 & $0,04^{*}$ & 43,73 & 4,4 & 44,63 & 4,8 & 0,43 \\
\hline Autonómia & $0,700^{*}$ & 0,01 & 48,82 & 18,4 & 53,41 & 17 & $-0,28$ & 54,49 & 17 & 46,3 & 17,6 & $0,76^{*}$ \\
\hline Szüloói kapcsolatok és otthoni élet & $0,611^{*}$ & $-0,01$ & 53,96 & 12,4 & 55,03 & 12,8 & 0,00 & 55,72 & 10,6 & 53,73 & 11,8 & 0,35 \\
\hline Pénzügyi források & 0,771 ** & $-0,01$ & 38,25 & 28 & 45,88 & 25,8 & $-0,45^{*}$ & 45,56 & 25,4 & 39,91 & 29 & 0,31 \\
\hline Társadalmi támogatás és társaik & $0,778^{* *}$ & $-0,003$ & 47,2 & 19,8 & 48,46 & 20,2 & $-0,08$ & 49,83 & 21 & 45,1 & 18,2 & 0,34 \\
\hline Iskolai környezet & 0,792 ** & 0,03 & 57 & 12,4 & 59,27 & 14,6 & 0,08 & 59,68 & 11,8 & 56,19 & 16,4 & 0,28 \\
\hline Társadalmi elfogadás & $0,701^{*}$ & $-0,002$ & 51,68 & 13,8 & 50,65 & 15,2 & 0,18 & 50,41 & 16 & 51,72 & 13,4 & $-0,13$ \\
\hline
\end{tabular}

átlag = átlag-KIDSCREEN-pontszámok; $\mathrm{r}=$ Pearson-féle korreláció; szignifikancia * $\mathrm{p}<0,05,{ }^{*} \mathrm{p}<0,001$

ANOVA = varianciaanalízis; ÁP = általános népesség; ES = Cohen-hatásmérték; ES-5 = gyermek-szülő effect size-ok; ES-6 = gyermek-serdülő effect size-ok; ES-7 = férfi-nói effect size-ok; Összes = a tíz KIDSCREEN-dimenzió pontszámainak átlaga; SD = standard deviáció 


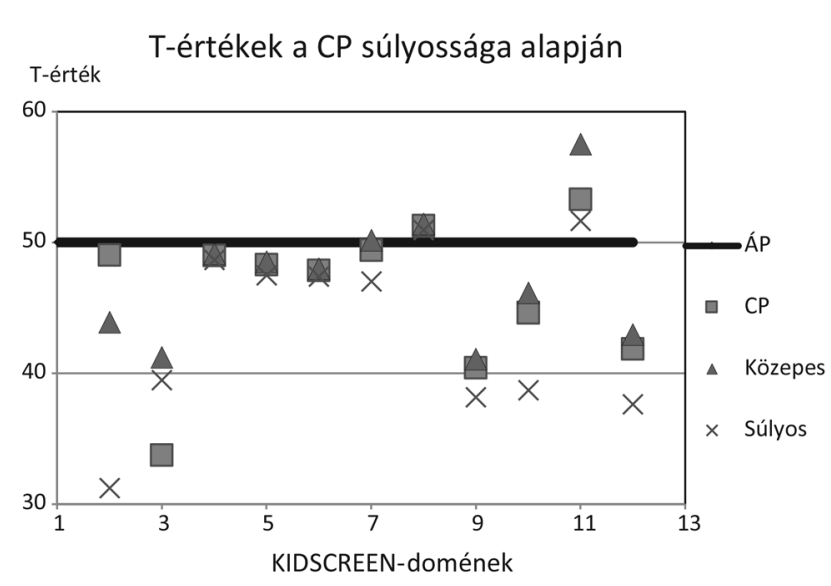

1. ábra fiúk ( $\mathrm{p}=0,020)$. A tíz dimenzióból a következő háromban voltak szignifikánsan alacsonyabbak a pontszámok a lányoknál: lelki jóllét, hangulat/érzések és autonómia $(\mathrm{p}=0,001-0,043$, ES: közepes-erős, 0,52-0,76) (4. táblázat). A CP-s lányok szülei az anyagi helyzetüket rosszabbnak ítélték meg, mint a fiúgyermekes szülők. Az anyagi helyzetet vizsgáló dimenzió átlaga a lányos szülő́k esetében 2,6 volt, míg a fiús szülőkk esetében $3,4(\mathrm{p}=$ 0,008 ).

A CP súlyossága nemcsak a testi jóllétet csökkenti jelentősen, de rontja az anyagi helyzetet, a szociális és baráti környezetet és a társadalmi elfogadottságot is. Mérhető különbség van a barátság, az iskolai környezet és a társadalmi elfogadottság dimenzióiban is $(\mathrm{p}=0,003-$ 0,004, ES: közepes, 0,6-0,69).

Az ÁP-hez viszonyítva a családi életet és az iskolai környezetet magasabb pontszámmal értékelték mindhárom, különböző súlyosságú CP-csoportban. Az 1. ábra a saját ÁP-t felhasználva az életminőségnek a referenciapopulációhoz viszonyított átlag-T-értékeit ábrázolja a CP súlyossági kategóriái szerint (1. ábra).

A mozgássérülés típusai szerint csoportosítva a CP-betegeket, a kétoldali spasticus CP-csoport ítélte a legrosszabbnak a testi jóllétet (ES az egyoldali és egyéb CP-hez viszonyítva: 0,$5 ;-1,7$ volt). Bár a többi életminőség-dimenzióban az egyoldali spasticus CP-ben szenvedők adták az alacsonyabbak értékeket, a három csoport között szignifikáns különbség nem állapítható meg. A családi és az iskolai környezet dimenzióinak kivételével valamennyi $C P$-típus válaszainak eredménye szignifikánsan elmaradt az ÁP-s csoport válaszaitól ( $\mathrm{p}<0,05$ szignifikanciaszint) (2. ábra).

Minél súlyosabb volt a mozgássérülés a GMFCS alapján, a testi jóllétnek annál alacsonyabb szintje volt mérhetô ( $\mathrm{p}=0,029$, ES: közepes, 0,5) (3. ábra).

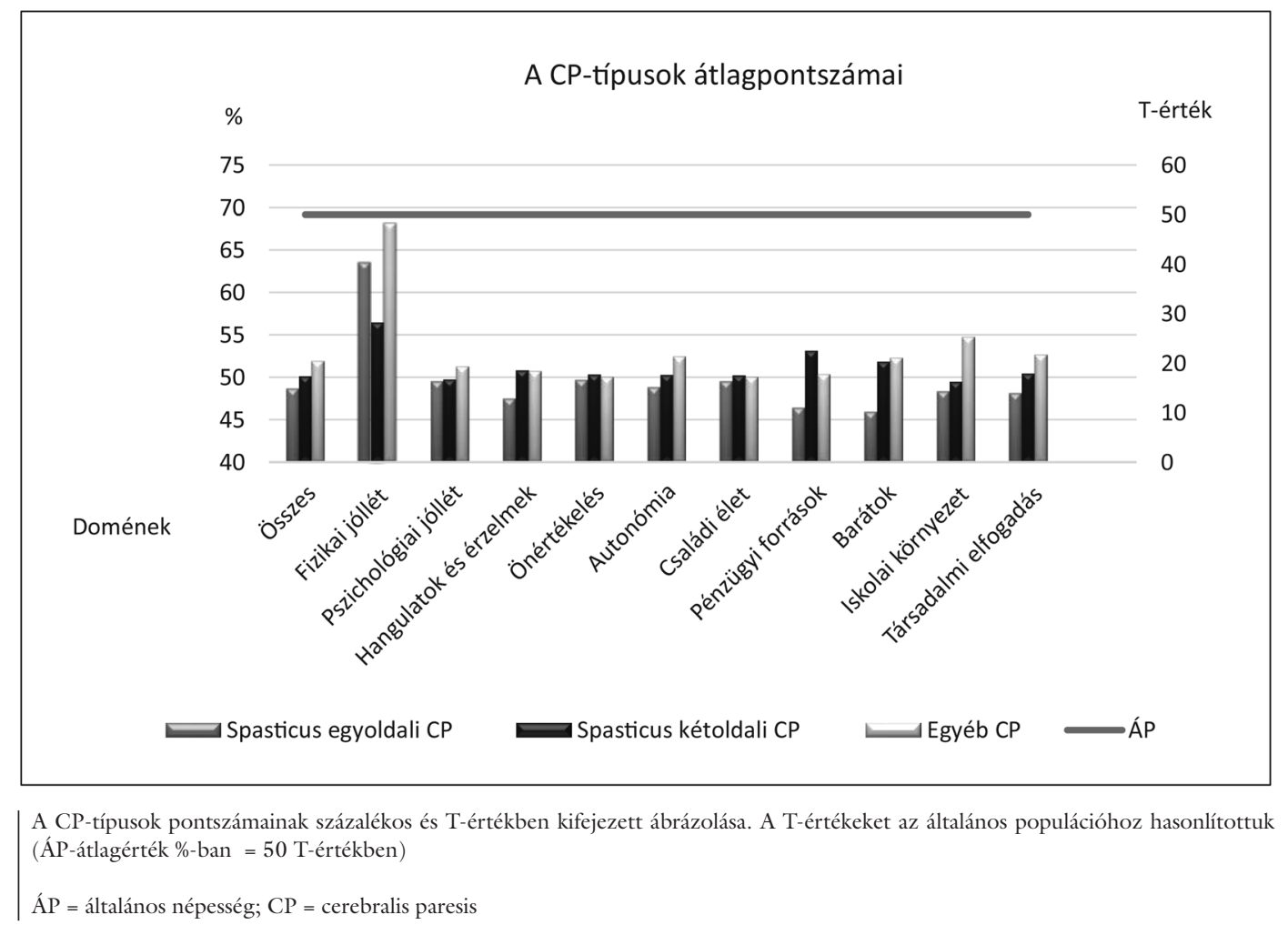



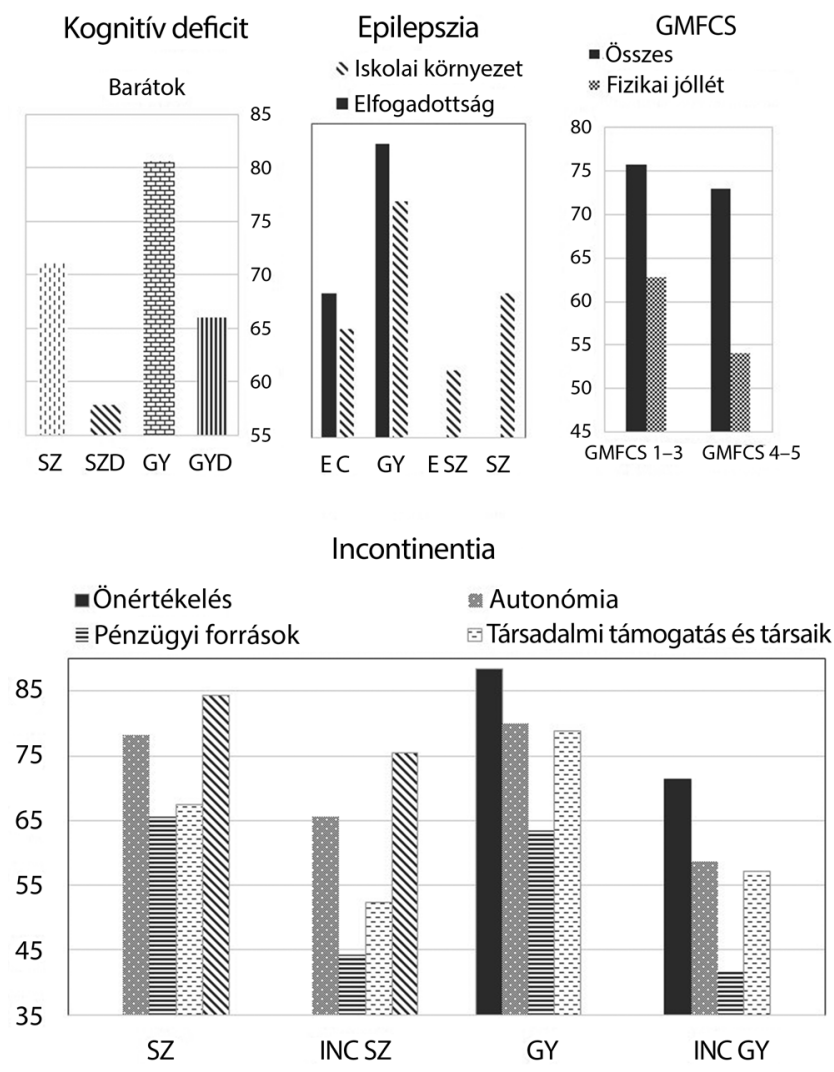

3. ábra

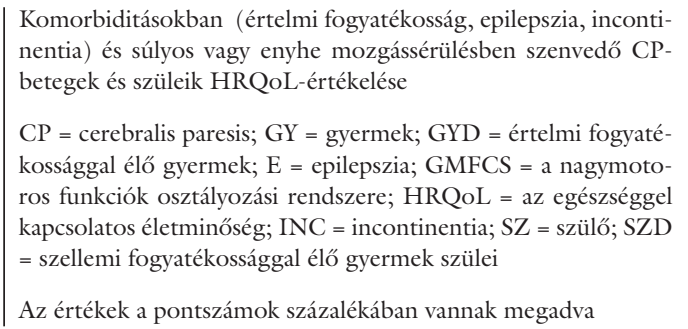

A CP-betegek több mint felének enyhe-közepes CDje volt. A CD negatív módon befolyásolja a szociális támogatottság, baráti kapcsolatok dimenzióját mind a gyermekek, mind a szüleik véleménye szerint $(\mathrm{p}=$ 0,019-0,007, ES: közepes, 0,61-0,51). Ezen gyermekek szülei magasabb fokúnak értékelték a stigma veszélyét (3. ábra).

Az epilepsziát, a CP társbetegségét tekintve a szülők és a gyermekek az iskolai környezetet $(\mathrm{p}=0,012, \mathrm{ES}: 0,55)$ és a szociális elfogadottságot $(\mathrm{p}=0,048-0,003$, ES: $0,63-0,99)$ szignifikánsan alacsonyabb értékúnek ítélték meg, mint az ÁP-csoport (3. ábra).

$\mathrm{Az}$ incontinentia elsóként a szociális életkörülményeket érinti. Abban az esetben, amikor a betegséghez incontinentia is társult, a CP-szülő́k és -gyermekek szignifikánsan rosszabbnak ítélték meg anyagi helyzetüket, a gyermekek önállóságát, a baráti kapcsolatokat és az iskolai környezetet, mint az ÁP-s csoport ( $\mathrm{p}=0,001-0,023$, ES: $0,71-0,95 ; \mathrm{p}=0,022$, ES: $0,7 \mathrm{l}-0,95$ ) (3. ábra).

A CP-betegek szülei között több mint 4-szer nagyobb arányban $(22 \%$ vs. $5 \%)$ voltak az alulképzettek ( $\leq 8$ általános iskolai osztály), mint az ÁP-szülők között. A gyermekek a testi jóllétet ítélték a legrosszabbnak ebben a csoportban. A CP-szülők közel fele inaktív dolgozó volt (RR: 2,85), akik gyermekeinek lelki jólléte elmaradt az aktív dolgozókéitól. A CP-gyermekek gyakran nőnek fel egyszülős családban (RR: 1,89). Itt a legnagyobb eltérést az életminőségben lehetett tapasztalni. Az összpontszám, valamint a testi-lelki jóllét és a hangulat dimenzióinak értékei elmaradtak a kétszülős családban élókéitől. Közülük sokan speciális iskolában vagy intézetben tanulnak (RR: 9,46). A normáliskolához viszonyítva szignifikánsan rosszabb a baráti kapcsolat és a társadalmi elfogadottság megítélése (5. táblázat). A CP-populációban

5. táblázat A táblázatban látható a szociodemográfiai mutatók gyakorisága és rizikója az általános populáció adataihoz viszonyítva, az egyes változók KIDSCREEN-52-pontszámának mértéke és a szignifikáns eltérést mutató domének neve, szignifikanciaszintje. A szociodemográfiai kérdőívet a szülók 85,86\%-a töltötte ki (85), de ez az adatmennyiség a statisztikai elemzéshez elégnek bizonyult

\begin{tabular}{|c|c|c|c|c|c|c|}
\hline Szociodemográfiai mutatók & $\mathrm{CP}(\mathrm{n} / \%)$ & ÁP $(\mathrm{n} / \%)$ & $\mathrm{RR}$ & Score-mérték & Eltérő domének & $\mathrm{p}$ \\
\hline \multicolumn{7}{|l|}{ Az anya képzettsége } \\
\hline$\leq 8$ osztály & $17 / 11,8$ & $12 / 5,1$ & 4,22 & $\downarrow$ & Fizikai jóllét & 0,030 \\
\hline Középfokú végzettség & $46 / 31,9$ & $119 / 50,2$ & 1,16 & $\uparrow$ & & \\
\hline Magasan képzett & $13 / 9,0$ & $95 / 40,1$ & 0,40 & $\leftrightarrow$ & & \\
\hline \multicolumn{7}{|l|}{ Az anya foglalkoztatottsága } \\
\hline Aktív & $40 / 27,7$ & $188 / 79,3$ & 0,65 & $\uparrow$ & Pszichológiai jóllét & 0,046 \\
\hline Inaktív & $34 / 23,6$ & $34 / 14,3$ & 2,85 & $\downarrow$ & & \\
\hline Családi állapot & & & & & Összes & 0,017 \\
\hline Kétszülős család & $58 / 40,2$ & $190 / 80,1$ & 0,87 & $\uparrow$ & Fizikai jóllét & 0,006 \\
\hline \multirow[t]{2}{*}{ Egyszülős család } & $19 / 13,9$ & $29 / 12,2$ & 1,89 & $\downarrow$ & Pszichológiai jóllét & 0,011 \\
\hline & & & & & Hangulat & 0,013 \\
\hline Iskola & & & & & Összes & 0,050 \\
\hline Normál & $34 / 23,6$ & $206 / 86,9$ & 0,49 & $\uparrow$ & Barátok & 0,045 \\
\hline Speciális & $42 / 29,2$ & $14 / 5,9$ & 9,46 & $\downarrow$ & Társadalmi elfogadottság & 0,048 \\
\hline
\end{tabular}

$\downarrow ; \uparrow ; \leftrightarrow=$ alacsonyabb, magasabb, közepes KIDSCREEN-pontértékek; ÁP = általános népesség; CP = cerebralis paresis; $\mathrm{p}=$ szignifikanciaszint; $\mathrm{RR}$ = kockázati arány; kétszülős család = házas, együttélés; egyszülős család = elvált, egyedülálló, özvegy 
nagyobb arányban fordulnak eló a nagycsaládok (RR: 2,5). A CP-betegeknek több beteg testvérük volt, és a testvérek között nagyobb gyakoriságú a CD (RR: 5,77). A városi és a községi életet élők között nem volt különbség. A vidéken élők aránya alacsonyabb volt a CP-betegek között (RR: 0,77).

\section{Megbeszélés}

A mozgás, az ortopédiai és a kognitív sérülések más-más szintű károsodásai jellemzőek a CP-ben szenvedő gyermekekre. Ezek a gyerekek különböző szinten akadályozott mértékű mozgással és önellátó képességgel rendelkeznek, ezért szociális beilleszkedésük is nehezített. A hagyományos orvosi kezelés elsősorban a betegek fizikai tüneteire összpontosít. A jelen kutatás nemcsak a CP-vel küzdő gyermekek fizikai és lelki egészségi állapotát kívánta megvizsgálni, hanem annak feltárását is célozta, hogy ez a fogyatékosság hogyan befolyásolja az egészséghez kötött életminőséget. Hazánkban hasonló vizsgálatokat CP-ben szenvedő gyermekekkel eddig még nem végeztek, csak kardiológiai betegek esetében folytak kutatások [29].

A jelen kutatásban összesen 99, CP-ben szenvedő és 237, hasonló életkorú és hasonló lakóhelyről származó ÁP-s gyermek és családja vett részt. A hangsúly fóleg a gyermekek és a serdülők véleményeire fókuszált, de értékes proxyadatok származtak a szülőktől is.

Megállapítható, hogy a szülők által adott pontszámok mindkét csoportban hasonlóak voltak a gyermekek válaszaihoz. A szülői kérdőívek véleménye kiegészítette a gyermekek értékelését a szülők számára jól ismert helyzetekben, például testi-lelki jóllét, de eltérő pontszámokat adott az önértékelés az iskolai környezet kérdéscsoportjaira. Nem meglepő, hogy az életminőség-pontszámok szignifikánsan alacsonyabbak voltak a CPcsoportban, mint az ÁP-ben $(\mathrm{p}<0,001)$. Hasonló eredményeket publikáltak más tanulmányokban [1315]. A CP-s gyermekek és szüleik a családi életüket (a szülők kapcsolata/otthoni élet) és az iskolai környezeti dimenziókat érdekesebbnek és kellemesebbnek értékelték, mint az ÁP-s gyermekek és szüleik. Ez arra utalhat, hogy a fogyatékossággal élő gyermekes családokban a kohézió erősebb lehet, mint a népesség többi családjában. Az a tény, hogy mind a CP-vel rendelkező gyermekek, mind a szüleik jobb pontszámokkal értékelték az iskolai környezetet, mint a „kontroll”családok, biztató lehet, különösen a gyermekek jelenlegi iskolai rendszerében. Szociológiai vizsgálatok alapján a fogyatékos egyén boldogsága a társadalmi támaszt nyújtó környezet esetén szubjektíven magasabb szintü [30].

Vizsgálatunkban a CP-s gyermekek életkor-specifikus, saját beszámolójában szereplő HRQoL-értékek hasonlóak voltak egymáshoz, de az idősebb gyermekek reálisabb és tájékozottabb képet közöltek anyagi helyzetükról. Más publikációkban több dimenzióban is életkor-specifikus különbséget mértek fel [17, 23]. A társadalmi-gaz- dasági környezetet és a hosszú távú eredményeket a család pénzügyi helyzete vagy az anya foglalkozása befolyásolta [20]. A felnőttkori vizsgálatok azt sugallják, hogy az életminőséget a leginkább az interperszonális kapcsolatok, a személyes fejlődés és a társadalmi elfogadottság befolyásolja, nem pedig a testi jóllét vagy az anyagi jólét [21].

Egy betegség gyermeki életminőségre gyakorolt hatásának a megértéséhez mind a gyermekek, mind a szülők szempontjai nélkülözhetetlenek [20, 21]. A gyermekekserdülők és a szüleik válaszai közötti korreláció erőssége alapvető információkat szolgáltat [18]. A vizsgált mintában a családi kohézió tükröződött a CP-s gyermekekserdülők és szüleik válaszai között. A korábbi vizsgálatokban a szülői HRQoL-értékelés a CP-csoportban alacsonyabb volt $[15,23]$. Vizsgálatunkban szignifikáns különbségek figyelhetők meg az ÁP-hez képest $(\mathrm{p}<0,000)$, és a korreláció ellenére szignifikáns különbségek fedezhetők fel a hat dimenzióban a CP-s gyermekek és szüleik között. Ezek a különbségek azt mutatják, hogy mind a betegség, mind a környezeti tényezők megváltoztatják a HRQoL-t [16, 17, 24].

A CP-ben szenvedő lányok szomorúbbnak ítélték érzelmi életüket a fiúkhoz képest, amint azt Tessier és mtsai is megfigyelték [22], valószínúleg annak következtében, hogy a testi megjelenés vagy a testkép a lányoknál nagyobb értéket képvisel.

A CP súlyosságával kapcsolatos megállapításaink megerôsítik néhány korábbi tanulmány eredményét. A súlyosabb mozgássérülést a magasabb GMFCS-pontszámokkal és a testi-lelki HRQoL alacsonyabb értékeivel társították [8, 20, 21]. A komorbiditások (például epilepszia, mentális károsodás, incontinentia) rontják a pszichoszociális HRQoL-t $[18,20,22]$. A család és a barátok dimenzióit a környezet közvetlenül rontja, ami javulhat a korai segítségnyújtással [19]. A felnőttkori vizsgálatok azt sugallják, hogy az életminőséget a leginkább az interperszonális kapcsolatok, a személyes fejlődés és a társadalmi befogadás jellemzi, nem pedig a fizikai jóllét vagy az anyagi jólét [21].

Az eredmények alapján megállapítható, hogy a CP súlyossága nemcsak a fizikai jóllétre volt figyelemre méltó hatással, hanem kihatott a pénzügyi forrásokra, a társadalmi támogatásra/barátokra és a társadalmi elfogadottság szintjére is. Power és mtsai arról számoltak be, hogy az alacsony és közepes jövedelmú országokban a CP-vel rendelkező gyermekek HRQoL-értéke minden szempontból szignifikánsan alacsonyabb az életkor szerinti kontrollokénál. Úgy találták, hogy a testi jóllétet értékelik a legalacsonyabb szintüre [31]. Mindenképpen figyelembe kell venni, hogy a családok költségei (szállítás, táplálkozás, gyógyszerek, pelenkák stb.) növekednek a CP súlyosságával. Emellett nyilvánvaló, hogy a súlyos CP-s gyermekeknek nagyobb társadalmi elfogadásra és támogatásra van szükségük. A szerzők kutatási eredményei jól korrelálnak Colver és mtsai adataival [17]. Serdülő CP-betegeket tanulmányozva az is megállapítható, 
hogy a károsodás súlyossága három területen is (hangulatok/érzelmek, autonómia és társadalmi támogatás/ társak) szignifikánsan $(\mathrm{p}<0,01)$ kapcsolódik a csökkent életminőséghez. A CP-vel rendelkező serdülők életminősége az ÁP-hez viszonyítva csak egy területen alacsonyabb szignifikánsan (szociális támogatás/társak; átlagos különbség -2,7 [0,25 SD], 95\% CI -4,3 és -1,4).

Figyelemre méltó, hogy a CP eloszlási típusai nem befolyásolják szignifikánsan a gyermekek teljes HRQoLértékét, ugyanakkor megállapítható, hogy a HRQoL általában alacsonyabb volt az egyoldali CP-típusú csoportban, mint a kétoldali és egyéb CP-típusokéban. Ezek alapján feltételezhetjük, hogy a test két oldala közötti múködési különbség ezeknek a gyermekeknek nagyon zavaró lehet. Mivel más adat nem erősítette meg ezt a feltételezést, célszerű további vizsgálatokat végezni a különféle CP-típusok nagyobb csoportjainak bevonásával.

Megállapítható, hogy a társuló szellemi fogyatékosság negatívan befolyásolja a társadalmi támogatást és a baráti kapcsolatokat. Az epilepszia mint a CP társbetegsége rontja azt iskolai környezet és a társadalmi elfogadottság/bántalmazás területén mért HRQoL-t az érintett gyermekek és szüleik szerint. Ez azt jelenti, hogy az epilepszia továbbra is megbélyegzés, az epilepsziás rohamokat elszenvedő gyermekeket osztálytársaik zaklatják, és tanáraikat szintén negatívan befolyásolja az epilepszia jelenléte.

A társuló incontinentia szintén rontja a gyermekek HRQoL-értékét; nemcsak önállóságuk, hanem társas kapcsolataik minősége is csökken a tünet következtében. Eredményeink igazolják a kortárs kapcsolatok és a barátságok fontosságát a CP-ben szenvedő gyermekek körében. Az incontinentia javulása az életminőséget is javítja [32].

A szociodemográfiai jellemzők igazolják a fogyatékossággal élő gyermeket gondozó szülők és családok hátrányos helyzetét. A gyermek tartós betegsége és az ennek következtében fellépő folyamatos lelki és anyagi nehézségek miatt a szülóknek nagy szükségük van megértésre, szociális támogatásra [33]. Az alacsonyabb iskolai végzettség 4-szer olyan gyakori; a munkaerőpiaci inaktivitás és az egyszülős család 2-szer nagyobb arányban fordul elő CP-s gyermekeknél, mint ÁP-s kortársaiknál. Ezek a gyermekek 2,5-szer nagyobb valószínüséggel nevelkednek többgyermekes családban. Testvéreik között a mentális betegség 5,7-szer gyakoribb. Az alacsonyabb anyai végzettség [34, 35] és az alacsonyabb társadalmi-gazdasági státusz növeli a CP kockázatát [35-37]. Mivel sok anyának kompromisszumot kell kötnie gyermekének gondozása és a foglalkozása között, az anyák inaktivitása magas. Több, CP-vel rendelkező gyermek él városokban. Hasonlóképpen számoltak be Jain és mtsai [38].

A bevont családok száma mindkét csoportban viszonylag magas volt. Tanulmányunk fó erőssége, hogy nemcsak a szülők értékelésén alapul, hanem a gyermekek véleményének megkérdezésén is. A viszonylag széles korosztály és a résztvevő csoportok száma lehetővé tette a gyermekek és a serdülők véleményének összehasonlítását. A szociodemográfiai környezet vizsgálata megerősítette a családok pénzügyi és mentális támogatásának szükségességét.

A kutatás egyik hiányossága, hogy a CP-populáció nem volt teljesen homogén a CP típusát és a GMFCSszinteket tekintve. Az eredmények értékelésekor nem hagyható figyelmen kívül, hogy a betegek többségénél súlyos társbetegségek kapcsolódtak az alapbetegséghez, amelyek negatívan befolyásolták a HRQoL-t. Mivel csak azoknak a gyermekeknek a véleményét ismerhettük meg, akik képesek voltak megválaszolni a kérdéseket, az eredmények csak a nem a legsúlyosabb fogyatékossággal élő gyermekek önálló véleményét tükrözik.

\section{Következtetések}

A krónikus fogyatékosság szignifikánsan rontja a CP-ben szenvedő gyermekek és serdülők egészséghez kötött életminőség-értékét. Az életkor, a GMFCS-status és a társbetegségek száma negatív hatást gyakorol több HRQoL-dimenzió értékelésére is. A nemek között szintén mutatkoznak szignifikáns különbségek: a CP-vel küzdő lányok a pszichoszociális életminőségük értékét alacsonyabbnak ítélték meg, mint a fiúk. Az összes, CPben szenvedő betegnél magasabb a T-érték a szülői és az iskolai környezetben, mint az ÁP-ben. Ebből arra lehet következtetni, hogy a fogyatékossággal élő gyermekek és serdülők jobban kötődnek szüleikhez és tanáraikhoz, mint az ÁP tagjai. A gyermek és a szülő által véleményezett HRQoL-pontszámok közötti különbség krónikus betegségek esetén jól ismert [39]. A CP súlyossága nagymértékben befolyásolja a gyermekek és szüleik életminőségét és szociodemográfiai státuszát.

A kutatás hozzájárul a szülők és CP-ben szenvedő gyermekeik pszichoszociális gondozási igényeinek azonosításához. Az eredmények alapján megállapítható, hogy pszichoszociális ellátásra nemcsak a CP-betegeknek, hanem családtagjaiknak is szükségük van. A krónikus betegségben szenvedő betegek egészséghez kötött életminőségének vizsgálatával foglalkozó felmérések a terápiás rekreációs programok pozitív hatásairól számolnak be $[40,41]$. Más kutatások eredményei pedig alátámasztják az életkoruknak megfelelő szabadidős tevékenységekben való részvétel szükségességét a serdülők számára [42]. Mindezek alapján levonható az a következtetés, hogy a családközpontú gondozás segítené ezeket a családokat, és javítaná az integrációs folyamatokat.

A vizsgálat eredményei igazolták, hogy a CP-vel rendelkező gyermekek megbízható ismeretekkel rendelkeznek állapotukról, és életminőségük visszatükrözi szociodemográfiai hátterüket.

Anyagi támogatás: A szerzók anyagi támogatásban nem részesültek. 
Szerzôi munkamegosztás: Az eredeti ötlet: H. K. Adatgyújtés: H. K., F. M. Adatbevitel: F. M., V. B. Statisztikai elemzés: F. M., V. B. Minden szerző egyetértett az adatok bemutatásával, értelmezésével és a kézirat megírásával. A cikk végleges változatát valamennyi szerző elolvasta és jóváhagyta.

Érdekeltségek: A szerzőknek nincsenek érdekeltségeik.

\section{Irodalom}

[1] Surveillance of cerebral palsy in Europe: Prevalence and characteristics of children with cerebral palsy in Europe. Dev Med Child Neurol. 2002; 44: 633-640.

[2] Fejes M, Varga B, Hollódy K. Epidemiology, cost and economic impact of cerebral palsy in Hungary. [A cerebralis paresis epidemiológiája, költségei és közgazdasági hatásai Magyarországon.] Ideggyógy Szle. 2019; 72: 115-122. [Hungarian]

[3] Fejes M, Szűts Á, Cservenyák J, et al. Epidemiologic status of cerebral palsy in our county with ultrasound follow-up. Year Book of Pediatric Radiology 2001; 12-13: 41-49.

[4] Jarvis S, Glinianaia SV, Torrioli MG, et al. Cerebral palsy and intrauterine growth in single births: European collaborative study. Lancet 2003; 362: 1106-1111.

[5] Shafer S, Moss K. Cerebral palsy and children with vision and hearing loss. Texas School for the blind and visually impaired. Available from: https://www.tsbvi.edu/cerebral-palsy-and-children-with-vision-and-hearing-loss-2 [accessed: May 4, 2019].

[6] Centers for Disease Control and Prevention. Data and statistics for cerebral palsy. Available from: www.cdc.gov/ncbddd/cp/ data.html [accessed: May 4, 2019].

[7] Singhi P, Jagirdar S, Khandelwal N, et al. Epilepsy in children with cerebral palsy. J Child Neurol. 2003; 18: 174-179.

[8] Cans C, McManus V, Crowley M, et al. Cerebral palsy of postneonatal origin: characteristics and risk factors. Paediatr Perinat Epidemiol. 2004; 18: 214-220.

[9] Vargus-Adams J. Health-related quality of life in childhood cerebral palsy. Arch Phys Med Rehabil. 2005; 86: 940-945.

[10] Chmielik LP, Chmielik A. A survey of health related quality of life (HRQL) in children with cerebral palsy. Borgis New Med. 2012; 4: 108-113.

[11] White-Koning M, Arnaud C, Dickinson HO, et al. Determinants of child-parent agreement in quality-of-life reports: a European study of children with cerebral palsy. Pediatrics 2007; 120: e804-e814

[12] Jardine J, Glinianaia SV, McConachie H, et al. Self-reported quality of life of young children with conditions from early infancy: a systematic review. Pediatrics 2014; 134: el 129-el148.

[13] Majnemer A, Shevell M, Rosenbaum P, et al. Determinants of life quality in school-age children with cerebral palsy. J Pediatr. 2007; 151: 470-475.e1-e3.

[14] Schneider JW, Gurucharri LM, Gutierrez AL, et al. Health-related quality of life and functional outcome measures for children with cerebral palsy. Dev Med Child Neurol. 2001; 43: 601-608.

[15] Oeffinger D, Gorton G, Bagley A, et al. Outcome assessments in children with cerebral palsy. Part I. Descriptive characteristics of GMFCS levels I to III. Dev Med Child Neurol. 2007; 49: 172180.

[16] Dickinson HO, Parkinson KN, Ravens-Sieberer U, et al. Self-reported quality of life of 8-12-year-old children with cerebral palsy: a cross-sectional European study. Lancet 2007; 369: 2171-2178

[17] Colver A, Rapp M, Eisemann N, et al. Self-reported quality of life of adolescents with cerebral palsy: a cross-sectional and longitudinal analysis. Lancet 2015; 385: 705-716.
[18] Ko J, Lee BH, Kim M. Relationship between function and health-related quality of life of school-aged children with erebral palsy. J Phys Ther Sci. 2011; 23: 189-195.

[19] Vasconcelos VM, Carvalho ZM, Ximenes LB, et al. Domains of quality of life of children suffering from cerebral palsy: a crosssectional study. [Domínios de qualidade de vida de crianças com paralisia cerebral: estudo transversal.] Online Braz J Nurs. 2014; 13: 613-621. [Brazilian Portuguese]

[20] Mohammed FM, Ali SM, Mustafa MA. Quality of life of cerebral palsy patients and their caregivers: a cross sectional study in a rehabilitation center Khartoum-Sudan (2014-2015). J Neurosci Rural Pract. 2016; 7: 355-361.

[21] Maestro-Gonzalez A, Bilbao-Leon MC, Zuazua-Rico D, et al. Quality of life as assessed by adults with cerebral palsy. PLoS ONE 2018; 13: e0191960.

[22] Tessier DW, Hefner JL, Newmeyer A. Factors related to psychosocial quality of life for children with cerebral palsy. Int J Pediatr. 2014; 2014: 204386.

[23] Gates P, Otsuka N, Sanders J, et al. Functioning and health-related quality of life of adolescents with cerebral palsy: self versus parent perspectives. Dev Med Child Neurol. 2010; 52: 843-849.

[24] Dobhal M, Juneja M, Jain R, et al. Health-related quality of life in children with cerebral palsy and their families. Indian Pediatr. 2014; 51: 385-387.

[25] Ravens-Sieberer U, Gosch A, Rajmil L, et al., and the European KIDSCREEN Group. KIDSCREEN-52 quality-of-life measure for children and adolescents. Expert Rev Pharmacoecon Outcomes Res. 2005; 5: 353-364.

[26] The KIDSCREEN Group Europe. The KIDSCREEN Questionnaires - Quality of life questionnaires for children and adolescents. Handbook. Pabst Science Publishers, Lengerich, 2006.

[27] SCPE Collaborative Group. Surveillance of Cerebral Palsy in Europe: a collaboration of cerebral palsy surveys and registers. Dev Med Child Neurol. 2000; 42: 816-824.

[28] Palisano R, Rosenbaum P, Walter S, et al. Development and reliability of a system to classify gross motor function in children with cerebral palsy. Dev Med Child Neurol. 1997; 39: 214-223.

[29] Berkes A, Pataki I, Kiss M, et al. Measuring health-related quality of life in Hungarian children with heart disease: psychometric properties of the Hungarian version of the Pediatric Quality of Life Inventory ${ }^{\mathrm{TM}} 4.0$ Generic Core Scales and the Cardiac Module. Health Qual Life Outcomes 2010; 8: 14.

[30] Szabó L. The happiness is relative. Disability and subjective quality of life. [A boldogság relatív. Fogyatékosság és szubjektív életminőség.] Szociol Szle. 2003; 3: 86-105. [Hungarian]

[31] Power R, King C, Muhit M, et al. Health-related quality of life of children and adolescents with cerebral palsy in low- and middleincome countries: a systematic review. Dev Med Child Neurol. 2018; 60: 469-479.

[32] Vajda P, Kispal Z, Lenart I, et al. Quality of life: urinary bladder augmentation or substitution in children. Pediatr Surg Int. 2009; 25: 195-201.

[33] Lima MBS, Cardoso VS, Silva SSC. Parental stress and social support of caregivers of cerebral palsy children. [Estresse parental e suporte social de cuidadores de crianças com paralisia cerebral.] Paidéia (Ribeirão Preto) 2016; 26: 207-214. [Brazilian Portuguese]

[34] Wu YW, Xing G, Fuentes-Afflick E et al. Racial, ethnic, and socioeconomic disparities in the prevalence of cerebral palsy. Pediatrics 2011; 127: e674-e681.

[35] Forthun I, Strandberg-Larsen K, Wilcox AJ et al. Parental socioeconomic status and risk of cerebral palsy in the child: evidence from two Nordic population-based cohorts. Int J Epidemiol. 2018; 47: 1298-1306.

[36] Solaski M, Majnemer A, Oskoui M. Contribution of socio-economic status on the prevalence of cerebral palsy: a systematic search and review. Dev Med Child Neurol. 2014; 56: 10431051 . 
[37] Tseng SH, Lee JY, Chou YL, et al. Association between socioeconomic status and cerebral palsy. PLoS ONE 2018; 13: e0191724.

[38] Jain V, Singh G, Jain JK, et al. Socio-demographic profile of cerebral palsy affected patients: an Indian scenario. Int J Cur Res Rev. 2015; 7: 15-18.

[39] Majnemer A, Shevell M, Law M, et al. Reliability in the ratings of quality of life between parents and their children of school age with cerebral palsy. Qual Life Res. 2008; 17: 1163-1171.

[40] Békési A, Török S, Kökönyei G, et al. Health-related quality of life changes of children and adolescents with chronic disease after participation in therapeutic recreation camping program. Health Qual Life Outcomes 2011; 9: 43
[41] Short KR, Frimberger D. A review of the potential for cardio metabolic dysfunction in youth with spina bifida and the role for physical activity and structured exercise. Int J Pediatr. 2012; 2012: 541363

[42] Shikako-Thomas K, Lach L, Majnemer A, et al. Quality of life from the perspective of adolescents with cerebral palsy: "I just think I'm a normal kid, I just happen to have a disability". Qual Life Res. 2009; 18: 825-832.

(Fejes Melinda dr., Miskolc, Szentpéteri kapu 72-76., 3526) e-mail: fejesmelindadr@gmail.com)

\section{Pályázati felhívás}

Dr. Fehér János professzornak, a Semmelweis Egyetem II. sz. Belgyógyászati Klinikája volt igazgatójának, az Orvosi Hetilap volt föszerkesztőjének emlékére 2011-ben alapítvány létesült.

A Dr. Fehér János Emlékére Alapítvány fö célja a belgyógyászat, különösen a hepatológia szabad gyökös és immunológiai vonatkozású témaköreinek kutatása, fejlesztése, támogatása, illetve ösztönzése oly módon, hogy az alapítvány kamatából fiatal egyetemi oktatók, $\mathrm{PhD}$-hallgatók és orvostanhallgatók részesüljenek.

A pályázatok benyújtásának határideje: 2021. április 15.

A dolgozatot „Dr. Fehér János pályázat” megjelöléssel kell benyújtani, és a pályázathoz mellékelni kell a pályázó önéletrajzát is.

A dolgozatot a Dr. Fehér János Emlékére Alapítvány Kuratóriuma elnökének

(Dr. Hagymási Krisztina) vagy titkárának (Dr. Lengyel Gabriella) kell eljuttatni.

Beküldési cím: Semmelweis Egyetem, I. Sebészeti és Intervenciós Gasztroenterológiai Klinika 1082 Budapest, Üllöi út 78.

A díj odaítéléséről a kuratórium dönt. A díj átadására az Orvosi Hetilap Markusovszky-ünnepségén kerül sor, ahol a nyertes pályázó 5 perces előadásban foglalhatja össze az eredményeit.

A cikk a Creative Commons Attribution 4.0 International License (https://creativecommons.org/licenses/by/4.0/) feltételei szerint publikált Open Access közlemény, melynek szellemében a cikk bármilyen médiumban szabadon felhasználható, megosztható és újraközölhető, feltéve, hogy az eredeti szerző és a közlés helye, illetve a CC License linkje és az esetlegesen végrehajtott módosítások feltüntetésre kerülnek. (SID_1) 